\title{
Quality Control in Plywood Manufacturing: Physical Properties of Commercial Plywood of Pinus sp
}

\author{
Diego H. Almeida ${ }^{1}$, Fabiane S. Ferro ${ }^{2}$, Luciano D. Varanda ${ }^{2}$, Amós M. de Souza², Felipe H. Icimoto \\ André L. Chris toforo ${ }^{3, *}$, Francis co A. Rocco Lahr ${ }^{1}$ \\ ${ }^{1}$ Department of Structural Engineering, En gin eering School of São Carlos (EESC/USP), São Carlos, 13566-590, Brazil \\ ${ }^{2}$ Department of Science and En gineering Materials, En gineering School of São Carlos (EESC/U SP), São Carlos, 13566-590, Brazil \\ ${ }^{3}$ Department of Mechanical Engin eering, Federal Univ ersity of São João del-Rei, São João del-Rei, 36307-352, Brazil
}

\begin{abstract}
Wood of genus Pinus have been widely used by plywood Brazilian industry, motivated by their good physical and mechanical properties as well as reforestation policies. For plywood companies, quality control for its commercialization presents itself as essential. In this sense, this paper aims to evaluate, by means of physical properties, homogeneity of plywood manufacturing process using Pinus sp. So, we selected four panels, and extracted samples to obtain their physical properties. Analys is of variance (ANOVA) was used to investigate manufacture homogeneity of the panels. ANOVA results, for all physical properties investigated, had presented statistical equivalence, showing consistency of product manufacture, independent of the supplier company.
\end{abstract}

Keywo rds Panels, Plywood, Physical Properties

\section{Introduction}

In Brazil, a greater investment in wood-based industry is enabling the use of wood with more rationality, given the circumstances that involve wood applications. In addition, knowledge of wood physical and mechanical properties is essential for its compatible utilization[1-2].

Among the techniques currently employed, using wood from planted forests is highlighted in the country. Reforestation of Pinus, Eucalyptus and Corymbia genus favor material for employing in construction, furniture industry and reconstituted wood panels [3].

Plywood is still an important wood-based product, made with veneers, juxtaposed with change between fiber direction, bonded with proper adhesive, under certain conditions of temperature and pressure[4]. Plywood can be used in various applications, such as in furniture industry and building construction[5-7].

Quality control in plywood manufacture is complex, once there are many elements that affect panel performance, including: options for hardwood or softwood [8-10]; pressing and temperature cycles applied[11]; and the kind of adhesive used[12-14].

Use of Pinus lumber in plywood manufacture is linked to reforestation of this species. Southern of Brazil is responsible for $83 \%$ of Pinus reforestation in the country,

* Corresponding author:

alchristo foro@y ahoo.com.br (André Luis Christoforo)

Published online at http://journal.sapub.org/cmaterials

Copyright (C) 2013 Scientific \& Academic Publishing. All Rights Reserved followed by the Southeast, with $14.3 \%$ [15], regions where a expressive number of companies are located.

Researches on Pinus sp. plywood physical properties characterization are systematically in developing, however focusing panels produced in laboratory scale[16-18].

Relying on the importance of quality control of panels produced industrially, this study aimed, with the aid of physical properties, evaluated the homogeneity of the industrial manufacturing process of plywood made with Pinus sp.

\section{Material and Methods}

For this research, four plywood panels obtained from different work shifts of a line production, in a company localized in São Carlos (SP-Brazil), were considered. Panels were manufactured with Pinus $\mathrm{sp}$ veneers, dimensions of $1.25 \mathrm{~m} \times 2.50 \mathrm{~m} \times 18 \mathrm{~mm}$, and using a phenolic resin to gluing.

From the panels, specimens were prepared to perform determination of the physical properties of the commercial plywood, according to Brazilian normative documents.

Tests were performed in water absorption ( 24 hours) recovery in thickness; swelling more recovery thickness swelling; and swelling.

\subsection{Water Absorption after 24 Hours}

Samples were weighed and then immersed in water for 24 hours and, subsequently, removed and weighed again. Absorption (A) in water after 24 hours (Equation 1) was 
obtained following assumptions and calculation methods of ABNT NBR 9486[19], using 6 specimens per panel.

$$
A=\frac{m_{f}-m_{i}}{m_{i}} \cdot 100
$$

In Equation 1, $A$ denotes the amount of water absorbed $(\%), m_{f}$ is the specimen final mass $(\mathrm{g})$ and $\mathrm{m}_{\mathrm{i}}$ is the specimen initial mass (g).

\subsection{Recovey in Thickness; Swelling more Recovery Thickness Swelling; and S welling}

To determine recovery in thickness; swelling more recovery thickness swelling; and swelling in plywood, after 24 hours of water absorption ABNT NRB 9535 recommendations were used[20].

From each panel, six specimens were prepared, dimensions $75 \times 25 \mathrm{~mm}$, packed in a climatic chamber $(25 \pm$ $2)^{\circ} \mathrm{C}$. These samples were separated in two sets (one of them considered as a control).

After first thickness measurement, made in the center of each specimen, those used as control were dried at $(103 \pm 2)^{\circ}$ $\mathrm{C}$ for 24 hours, taken to the desiccator and measured again.

The other specimens set was immersed in distilled water at $(20 \pm 2)^{\circ} \mathrm{C}$ during 24 hours. After this period, specimens were measured, dried at $(103 \pm 2)^{\circ} \mathrm{C}$ for 24 hours, taken to the desiccator and measured again. Thickness recovery; swelling more thickness; swelling in water after 24 hours were calculated using Equations 2, 3 and 4 respectively.

$$
\begin{gathered}
R E=\left(\frac{e_{1} \cdot e_{5}}{e_{2} \cdot e_{3}}-1\right) \cdot 100 \\
I R=\left(\frac{e_{1} \cdot e_{4}}{e_{2} \cdot e_{3}}-1\right) \cdot 100 \\
I=I R-R E
\end{gathered}
$$

In Equations 2, 3 and 4, $\mathrm{e}_{1}$ denotes the sum of specimens thickness (mm) of control set (air-conditioned); $e_{2}$ is the sum of the thicknesses of the control set specimens (oven dried); $\mathrm{e}_{3}$ is the sum of specimens thicknesses before immersion in water; $e_{4}$ is the sum of the specimens thicknesses after immersion in water; and $e_{5}$ is the sum of the specimens thicknesses after immersion in water (oven dried).

\subsection{Statistical Analysis}

To evaluate possible differences between physical properties of plywood panels manufactured with Pinus sp., analysis of variance (ANOVA) was used, in which the panel fro $\mathrm{m}$ where samples were extracted is the factor investigated, associated to four levels (number of selected panels). ANOVA was considered at level of significance $(\alpha) 5 \%$; equivalence between mean values for physical properties as null hypothesis $\left(\mathrm{H}_{0}\right)$; and non-equivalence as alternative hypothes is $\left(\mathrm{H}_{1}\right)$. P-value less than significance level implies rejecting $\mathrm{H}_{0}$, accepting it otherwise.
For ANOVA validation, were evaluated: normality (Anderson-Darling), in distribution of responses, and homogeneity between variances by treatment (Bartlett and Levene). Both tests were considered at the $5 \%$ significance level. Anderson-Darling test considered normal distributions to null hypothesis, and non-normality as alternative hypothesis. P-value greater than significance level involves accepting $\mathrm{H}_{0}$, rejecting it otherwise. Bartlett and Levene tests have equivalence of variances among treatments as null hypothesis and alternative hypothesis as non-equivalence. $\mathrm{P}$-value greater than significance level involves accepting $\mathrm{H} 0$, rejecting it otherwise.

\section{Results}

Tables 1-4 present results of physical properties obtained for each plywood panel: sample mean $(\bar{X})$; coefficient of variation $(\mathrm{Cv})$; smallest (Min) and largest (Max) values found, respectively.

Table 1. Physical properties, panel 1

\begin{tabular}{ccc}
\hline Parameters & A (\%) & RE (\%) \\
\hline $\bar{x}$ & 62.69 & 9.49 \\
Cv & 11 & 13 \\
Min & 58.71 & 8.93 \\
Max & 68.19 & 10.19 \\
\hline Parameters & IR (\%) & $\mathbf{I}(\mathbf{\%})$ \\
\hline $\bar{x}$ & 11.35 & 2.75 \\
Cv & 9 & 12 \\
Min & 10.79 & 2.71 \\
Max & 11.98 & 2.82 \\
\hline
\end{tabular}

Table 2. Physical properties, panel 2

\begin{tabular}{ccc}
\hline Parameters & A (\%) & RE (\%) \\
\hline $\bar{x}$ & 60.88 & 9.84 \\
$C v$ & 13 & 9 \\
Min & 57.13 & 8.88 \\
Max & 67.82 & 10.29 \\
\hline Paramete rs & IR (\%) & I (\%) \\
\hline $\bar{x}$ & 11.90 & 2.53 \\
$C v$ & 12 & 10 \\
Min & 10.39 & 2.71 \\
Max & 13.04 & 2.81 \\
\hline
\end{tabular}

Table 3. Physical properties, panel 3

\begin{tabular}{ccc}
\hline Parameters & A (\%) & RE (\%) \\
\hline $\bar{x}$ & 61.76 & 9.52 \\
C $v$ & 9 & 11 \\
Min & 54.57 & 8.57 \\
Max & 61.96 & 10.82 \\
\hline Parameters & IR (\%) & I (\%) \\
\hline $\bar{x}$ & 11.27 & 2.93 \\
Cv & 12 & 9 \\
Min & 10.12 & 2.74 \\
Max & 12.32 & 2.78 \\
\hline
\end{tabular}


Table 4. Physical properties, panel 4

\begin{tabular}{ccc}
\hline Paramete rs & A (\%) & RE (\%) \\
\hline $\bar{x}$ & 62.45 & 9.11 \\
$C v$ & 10 & 10 \\
Min & 58.42 & 8.84 \\
Max & 66.71 & 9.50 \\
\hline Paramete rs & IR (\%) & I (\%) \\
\hline $\bar{x}$ & 12.16 & 2.75 \\
$C v$ & 12 & 9 \\
Min & 10.99 & 2.70 \\
Max & 14.49 & 2.98 \\
\hline
\end{tabular}

Figures 1 and 2 show results of normality test and variance homogeneity evaluation test, respectively. As P-values are both higher than significance level for each physical properties investigated, distributions can be considered as normal and variances between treatments equivalent, validating ANOVA model.

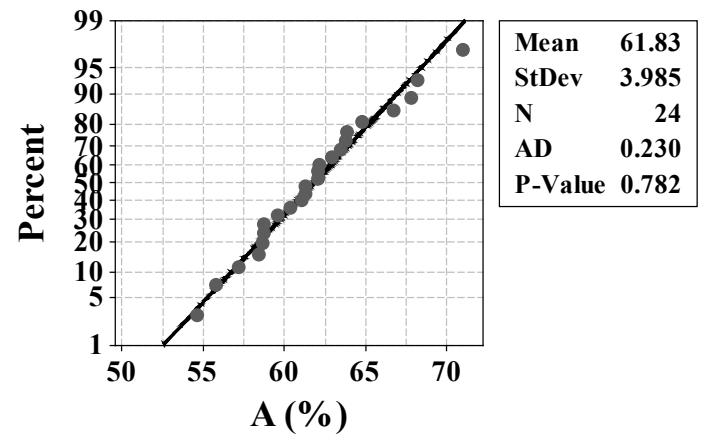

(a)

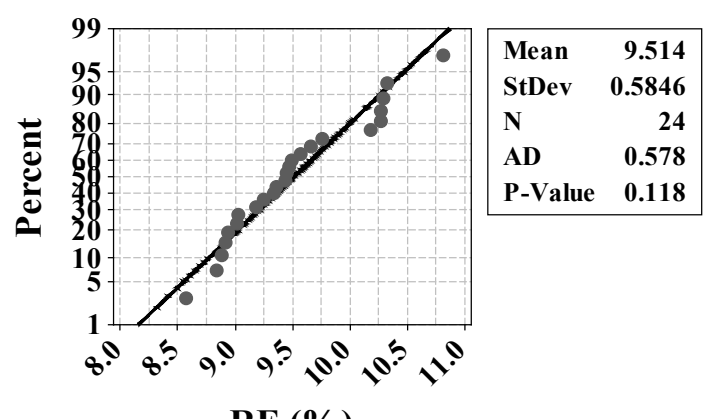

(b)

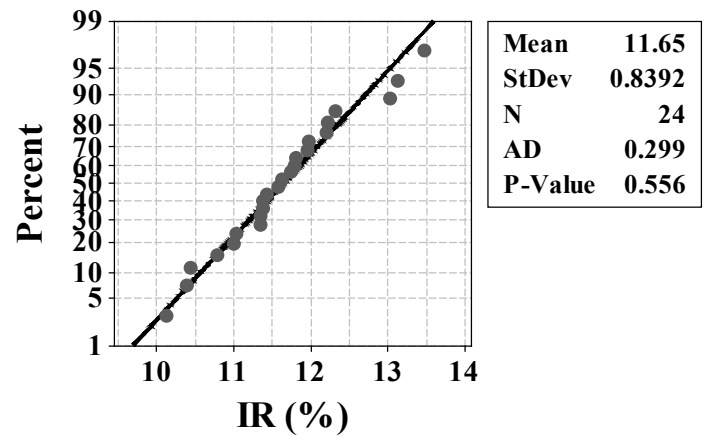

(c)

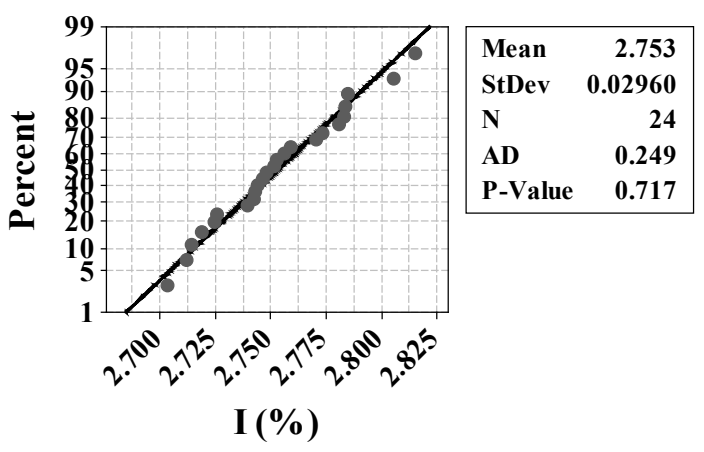

(d)

Figu re 1. Normality test results

Test for Equal Variances for A (\%)

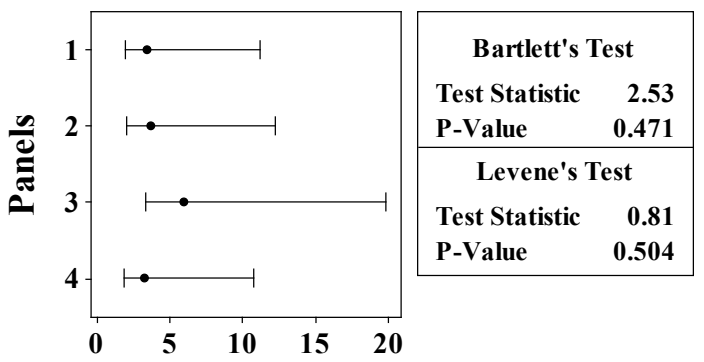

95\% Bonferroni Confidence Intervals for StDevs

(a)

Test for Equal Variances for RE (\%)

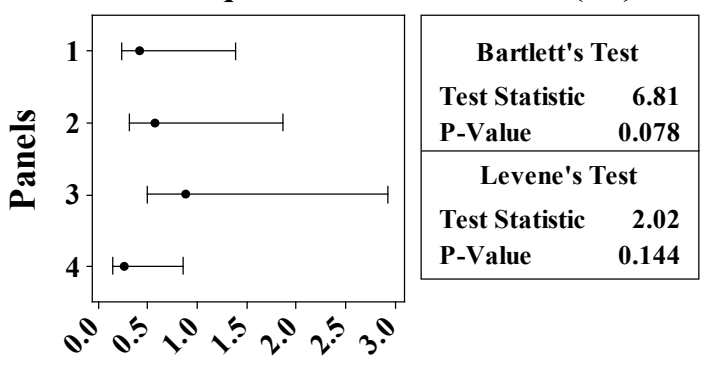

95\% Bonferroni Confidence Intervals for StDevs

(b)

\section{Test for Equal Variances for IR (\%)}

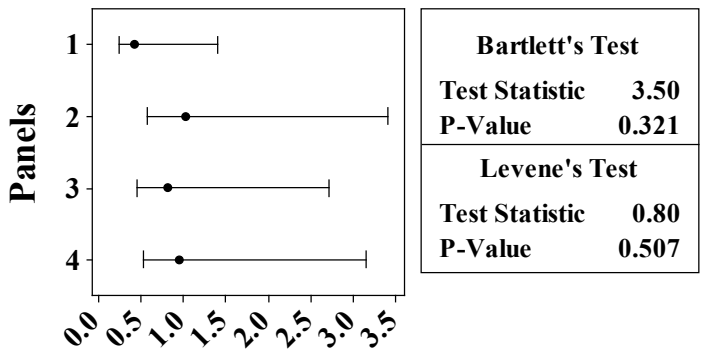

95\% Bonferroni Confidence Intervals for StDevs

(c) 


\section{Test for Equal Variances for I (\%)}

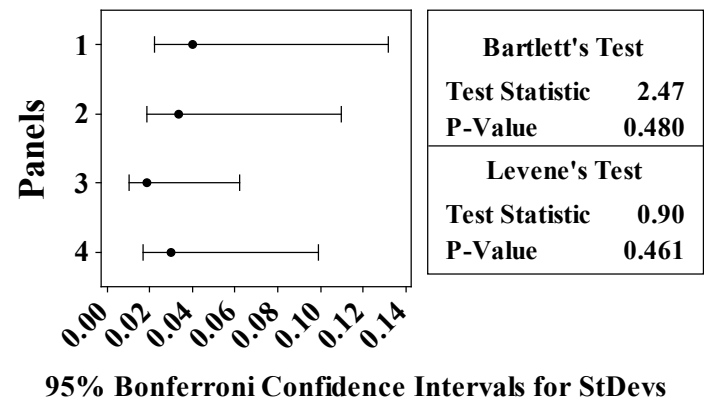

(d)

Figu re 2. Variance homogeneity test results

Tables 5-8 show ANOVA results (factor: panel) for each response variable of interest. As P-values found are higher than level of significance level $(5 \%), \mathrm{H}_{0}$ is accepted, imply ing that properties of all selected panels are equivalent, confirming homogeneity of manufacturing process of the company.

Table 5. ANOVA resultsto water absorption after 24 hours (A)

\begin{tabular}{cccccc}
\hline Source & DF & SS & MS & F & P-value \\
\hline Panels & 3 & 12,7 & 4,2 & 0,24 & 0,867 \\
Error & 20 & 352,5 & 17,6 & & \\
Total & 23 & 365,2 & & & \\
\hline
\end{tabular}

Table 6. ANOVA results for thickness recovering (RE).

\begin{tabular}{cccccc}
\hline Source & DF & SS & MS & F & P-value \\
\hline Panels & 3 & 1,21 & 0,40 & 1,21 & 0,332 \\
Error & 20 & 6,66 & 0,33 & & \\
Total & 23 & 7,86 & & & \\
\hline
\end{tabular}

Table 7. ANOVAresultsto swelling more thickness recovering (IR)

\begin{tabular}{cccccc}
\hline Source & DF & SS & MS & F & P-value \\
\hline Panels & 3 & 2,24 & 0,75 & 1,1 & 0,384 \\
Error & 20 & 13,96 & 0,70 & & \\
Total & 23 & 16,20 & & & \\
\hline
\end{tabular}

Table 8. ANOVAresultsto swelling in thickness (I)

\begin{tabular}{cccccc}
\hline Source & DF & SS & MS & F & P-value \\
\hline Panels & 3 & $6,7 \cdot 10^{-4}$ & $2,2 \cdot 10^{-3}$ & 0,23 & 0,875 \\
Error & 20 & 0,019 & $9,7 \cdot 10^{-3}$ & & \\
Total & 23 & 0,020 & & & \\
\hline
\end{tabular}

\section{Conclusions}

ANOVA results on physical properties revealed statistical equivalence among plywood panels, showing the good standard and consistency of manufacturing panels of the considered company, whose production is geared both for import and for export.

\section{ACKNOWLEDGEMENTS}

The authors express their gratitude to CAPES and CNPq for granting scholarships and the Inter Science and Engineering of Materials Department, Wood and Timber Structures Laboratory, Structural Engineering Department, USP São Carlos that enabled the development of this research.

\section{REFERENCES}

[1] Icimoto, F. H.; Ferro, F. S.; Almeida, D. H.; Christoforo, A. L.; Rocco, F. A. L. Influence of the wood specimen position on calculus of the bending modulus of elasticity. International Journal of Materials Engin eering, n. 3, v. 3, p. 41-46, 2013.

[2] Ferro, F. S.; Icimoto, F. H.; Almeida, D. H.; Christoforo, A. L.; Rocco, F. A. L. Verification of test conditions to determine the compression modulus of elasticity of wood. International Journal of Agriculture and Forestry, n. 2, v. 3,p. 66-70, 2013.

[3] Bertolini, M. S. Emprego de resíduos de Pinus sp tratado com preservante $\mathrm{CCB}$ na produção de chapas de partículas homogêneas utilizando resina poliuretana à base de mamona. Dissertação de Mestrado. Escola de Engenh aria de São Carlos, Universidade de São Paulo, São Carlos, 2011.

[4] Iwakiri, S. Painéis de madeira reconstituída. Curitiba - PR: FUPEF, 2003. 254 p.

[5] Stamato, G. C.; Calil Junior, C. Resistência ao embutimento da madeira compensada. Cadernos de Engenharia de Estruturas, n. 18, p. 49-76, 2002.

[6] Stamato, G. C. Resistência ao embutimento da madeira compensada. Dissertação de M estrado. Escola de Engenharia de São Carlos, Universidade de São Paulo, São Carlos, 1998.

[7] Dias, F. M. Ap licação de resina poliuretana à base de mamona na fabricação de painéis de madeira compensada e aglomerada. Tese de Doutorado. Escola de En genharia de São Carlos, Universidade de São Paulo, São Carlos, 2005.

[8] Iwakiri, D.; Nielsen, I. R.; Alberti, R. A. R. Avaliação da influência de diferentes composições de lâminas em compensados estruturais de Pinus elliottii e Eucalyptus saligna. Revista Cerne, v. 6, n. 2, p. 19-24, 2000.

[9] Jamalirad, L.; Doosthoseini, K.; Koch, G.; Mirshokraie, S. A.; Hedjazi, S. Physical and mechanical properties of plywood maufactured from treated Red-Heart Beech (Fagus orientalis L.) wood veneers. Bio Resourses, v. 6, n. 4, p. 3973-3986, 2011.

[10] Tenório, C.; Moya, R.; Camacho, D. Propriedades fisico-mecánicas de tableros terciados construidos con especies tropicales de plantaciones para uso estructural. Revista Cerne, v. 18, n. 2, p. 317-325, 2012.

[11] Ferreira, B. S.; Silva, M. S.; Campos, C. I. Análise do desempenho físico-mecânico de compensados produzidos com adesivos a base de PVA. Revista Madeira: Arquitetura e Engenharia, v. 12, n. 29, p. 13-22, 2011. 
[12] Khalil, H. P. S. A.; Fazita, M. R. N.; Bhat, A. H.; Jawaid, M.; Fuad, N. A. N. Development and material properties of new hybrid plywood from oil palm biomass. Materials and Design, v. 31, p. 417-424, 2010.

[13] Lima, N. N.; Pio, N. S.; Cunha, U. S.; Lucas Filho, F. C.; Barbosa Filho, J. Influência da gramatura na resistência da linha de cola aos esforços de cisalahamento em painéis compensados de Copaifera duckei Dawyer e Eperua olaifera Ducke. Acta Amazônica, v. 41, n. 1, p. 83-90, 2011.

[14] Silva, B. C.; Vieira, M. C.; Oliveira, G. L.; Gonçalves, F. G.; Rodrigues, N. D.; Lelis, R. C. C.; Iwakiri, S. Qualidade de compensados fabricados com adesivos à base de tanino-formaldeído de Pinus oocarpa e fenol-formaldeído. Floresta e Ambiente, v. 19, n. 4, p. 511-519, 2012.

[15] Associação Brasileira de Produtores de Florestas Plantadas (ABRAF): Anuário estatístico da ABRAFR 2012 ano base 2011. Brasília, 2012.
[16] Palma, H. A. L. Determinação de propriedades elásticas e de resistência em compensados de Pinus elliottii. Scientia Forestalis, n.51, p. 37-48, 1997.

[17] Albino, V. C. S.; Sá, V. A,. Bufalino, L.; Mendes, L. M.; Almeida, N. A. Avaliação das propriedades físico-mecânicas de painéis compensados de Toona ciliata M. Roem. var. australis. Revista Cerne, v.17, n.1, p. 103-108, 2011.

[18] Almeida, N. F.; Bortolleto Junior, G.; Mendes, R. F.; Suardi, P. G. Avaliação da madeira de Pinus elliottii var. elliottii $\mathrm{x}$ Pinus caribaea var. hondurensis para produção de compensados. Scientia Forestalis, v. 40, n. 96, p. 435-443, 2012.

[19] Associação Brasileira de Normas Técnicas (ABNT): NBR9486. Compensado: determinação da absorção de água. Rio de Janeiro, 1986.

[20] Associação Brasileira de Normas Técnicas (ABNT): NBR9535. Compensado: determinação do inchamento. Rio de Janeiro, 1986. 